\title{
Evaluation of Malaria Cases Detected in Antalya Province between 2012 and 2017
}

\author{
Antalya İlinde 2012-2017 Yilları Arasinda Saptanan Sitma Olgularnin \\ Değerlendirilmesi \\ (1) Önder Ser \\ Antalya Provincial Directorate of Health, Public Health Laboratory, Antalya, Turkey
}

Cite this article as: Ser Ö. Evaluation of Malaria Cases Detected in Antalya Province between 2012 and 2017. Turkiye Parazitol Derg 2020;44(1):1-6.

\begin{abstract}
Objective: Malaria is an important infectious disease that is transmitted by female mosquitoes of the genus Anopheles infected with parasites of the genus Plasmodium. In this research, it was aimed to contribute to the ongoing studies on malaria control in Antalya.

Methods: In this study, malaria data between 2012-2017 obtained from Antalya Provincial Directorate of Health were used. The patients with malaria were evaluated in terms of the years and months they were detected in, age group, gender, parasite species which were detected and their sources.

Results: During the 6-year period, a total of 1905 blood samples were surveyed and 36 (1.89\%) patients were reported. The most patients occurred in June and August (5 patients in each month, 13.89\%). Of the patients, $94.44 \%$ (34 patients) were 15 years old and over. By gender, $83.33 \%(n=30)$ of patients were male, $16.67 \%(n=6)$ were female. The disease agent responsible for most of the patients with malaria was P. falciparum ( $80.55 \%, 29$ patients), followed by P. vivax (11.11\%, 4 patients), P. ovale (5.56\%, 2 patients) and P. malariae (2.78\%, 1 patient). All patients with malaria were from abroad.
\end{abstract}

Conclusion: For malaria control, studies on the early diagnosis and treatment of the disease and the integrated mosquito control programs should be uninterruptedly maintained.

Keywords: Anopheles, Antalya, epidemiology, malaria, Plasmodium

ÖZ

Amaç: Sıtma, Plasmodium cinsi parazitlerle enfekte olmuş Anopheles cinsi dişi sivrisinekler tarafından bulaştırılan önemli bir enfeksiyon hastalığıdır. Bu araştırmada, Antalya ilinde sıtma mücadelesine yönelik sürdürülecek çalışmalara katkı sunulması amaçlanmiştır.

Yöntemler: Bu çalışmada, Antalya İl Sağlık Müdürlügü’nden elde edilen 2012-2017 yıllarına ait sıtma verileri kullanılmıştır. Sitma olguları yıllara, aylara, yaş gruplarına, cinsiyete, parazit türlerine ve kaynaklarına göre değerlendirilmiştir.

Bulgular: Altı yıllık bu dönemde, toplam 1905 kan örneği incelenmiş ve $36(\% 1,89)$ sıtma olgusu rapor edilmiştir. Olguların en fazla Haziran ve Ağustos aylarında [(beşer olgu \%13,89)] meydana geldiği görülmüştür. Olguların \%94,44 oranında (34 olgu) 15 yaş ve üzeri kişilerde görüldügü tespit edilmiştir. Olguların \%83,33'ü (30 olgu) erkek, \%16,67'si (6 olgu) kadındır. Sitma olgularının çoğundan sorumlu hastalık etkeni P. falciparum (\%80,55, 29 olgu) olup, bunu P. vivax (\%11,11, 4 olgu), P. ovale (\%5,56, 2 olgu) ve $P$. malariae (\%2,78, 1 olgu) takip etmektedir. Sitma olgularının tamamı yurt dışı kaynaklıdır.

Sonuç: Sitmanın kontrolü için, hastalı̆̆ın erken tanı ve tedavisine yönelik çalışmaların ve entegre sivrisinek mücadelesinin kesintisiz olarak sürdürülmesi gerekmektedir.

Anahtar Kelimeler: Anopheles, Antalya, epidemiyoloji, sitma, Plasmodium

\section{INTRODUCTION}

Malaria is the most important vector-borne infectious disease that significantly affects community health throughout history. The disease, which is common in tropical and subtropical regions, is caused by genus Plasmodium, one-celled intracellular protozoan parasites (1). Malaria parasites that cause disease in humans throughout the world are Plasmodium falciparum, P. vivax, P. ovale, P. malariae and P. knowlesi. Plasmodium falciparum, which is common in Africa, causes the most severe and most fatal malaria cases.

Received/Geliş Tarihi: 11.06.2019 Accepted/Kabul Tarihi: 13.11.2019

Address for Correspondence/Yazar Adresi: Önder Ser, Antalya Provincial Directorate of Health, Public Health Laboratory, Antalya, Turkey Phone/Tel: +90 2423466468 E-mail/E-Posta: onderser62@hotmail.com ORCID ID: orcid.org/0000-0002-0615-4962 
Plasmodium vivax is the most common species worldwide, but is less dangerous. Plasmodium malariae, $P$. ovale and $P$. knowlesi are less common species than the others (2).

Malaria parasites are transmitted from one human to another by a female mosquito of the genus Anopheles who has sucked blood from a person infected with parasites of the genus Plasmodium. In addition, it is known that these parasites can pass from a pregnant woman to her fetus and they can also be transmitted by blood transfusion, organ transplantation and contaminated medical materials (3-5).

Around 70 species of Anopheles, which are represented by approximately 470 species in the worldwide, are capable of transmitting human malaria parasites, of which about 40 species are known to be the dominant vector of malaria parasites $(6,7)$. Anopheles sacharovi and An. superpictus are the major vectors in malaria transmission in Turkey $(2,8)$.

According to 2017 malaria report of the World Health Organization (WHO); In 2016, an estimated 216 million cases of malaria were detected globally and approximately $90 \%$ of cases were reported in the WHO African Region. Indigenous malaria cases from 91 countries were reported in 2016. It is indicated that an estimated 445 thousand deaths from malaria occurred worldwide in 2016 and $91 \%$ of deaths occurred in the WHO African Region. $80 \%$ of global malaria burden and deaths occurred in 15 countries, all of which, excluding India, are sub-Saharan African countries. Plasmodium falciparum is the most common malaria parasite in sub-Saharan Africa, constituting 99\% of estimated malaria cases in 2016 (9).

Clinical features of malaria vary with parasite species, parasitemia level and patient's immune status. Following the bite by an infected female mosquito of the genus Anopheles, an incubation period of 7-30 days begins. After this period, non-specific symptoms such as malaise, fatigue, nausea, vomiting, anorexia, headache, myalgias and joint pain lasting several days is seen. Then, the typical malaria paroxysms begin with chills, rigors, high fever and sweating $(4,10)$.

Examination of thin and thick blood smears by a light microscope is accepted as the gold standard for the diagnosis of malaria parasites. At the same time, various rapid diagnostic tests are frequently used to assist with microscopic diagnosis or in field surveys where there is no microscopic diagnosis. In addition to these methods, serologic diagnostic methods and molecular diagnostic methods such as polymerase chain reaction (PCR) are used in the diagnosis of malaria parasites $(11,12)$.

Artemisinin-based combined therapy is particularly effective for the treatment of uncomplicated malaria cases caused by $P$. falciparum. Although there are a number of research projects aimed at developing vaccines against especially $P$. falciparum, there is still no licensed available vaccine that can protect people from malaria parasites $(13,14)$.

There are two main strategies for the control of malaria. The first strategy is the control of vector mosquitoes, the second is the early diagnosis and treatment of patients. Furthermore, people who will travel to the countries where the malaria is endemic should be informed about the disease and prevention methods. Also, it is necessary to give chemoprophylaxis against malaria parasites and provide personal protective measures (such as the use of mosquito nets and repellent products) against mosquitoes to these people $(1,2)$.
Antalya province, the fifth most populated city in Turkey in terms of population, is an important tourism and agricultural center. In this study, it was aimed to evaluate the general condition of malaria cases in Antalya province and to contribute to the ongoing studies on malaria control.

\section{METHODS}

In this study, malaria data between 2012 and 2017 obtained from Antalya Provincial Directorate of Health were used. In this period, blood samples were taken by using active and passive surveillance methods for the diagnosis of malaria in Antalya province. The laboratory diagnosis of blood samples was made by the Antalya Provincial Directorate of Health, Public Health Laboratory. In the laboratory, thin smear and thick drop blood preparations were stained with Giemsa and examined under a light microscope. Furthermore, the blood samples were investigated by rapid diagnostic tests. Blood samples that were difficult to diagnose were sent to Microbiology Reference Laboratory in Ankara for confirmation. In this center, in addition to both methods, detection and species identification of malaria parasites were carried out using the molecular diagnosis method (PCR). Malaria cases diagnosed in this way were evaluated retrospectively according to years, months, age groups, genders, parasite species and their sources. The ethics committee approval was not obtained due to the retrospective nature of the study.

\section{RESULTS}

According to the data obtained, a total of 1905 blood samples were examined for the diagnosis of malaria in the six-year period between 2012 and 2017 in Antalya province. In 36 of them, malaria parasite was found and the rate of positivity was $1.89 \%$. By gender, while $83.33 \%$ (30 cases) of malaria cases were male, $16.67 \%$ (six cases) were female. The disease agent responsible for most of the malaria cases was $P$. falciparum (80.55\%, 29 cases), followed by $P$. vivax (11.11\%, four cases), P. ovale (5.56\%, two cases) and P. malariae (2.78\%, one case). Two of the three cases of $P$. vivax were seen as recurrence from the same patient (Table 1 ).

Malaria cases detected in between 2012 and 2017 were in the 4-71 years age range and $94.44 \%$ of the cases (34 cases) were found in people 15 years old and over. While no positive case was detected in $0-1$ and 10-14 age groups, one case was detected in each of the 1-4 and 5-9 age groups (Table 2).

All of the detected malaria cases in Antalya province between 2012 and 2017 were from abroad and no indigenous cases of malaria were observed in this period. It was determined that 35 (97.22\%) of the patients had a travel history to African countries and one (2.78\%) to India or they came from these countries (Table 3). 31 of malaria patients (86.11\%) are citizens of the Republic of Turkey, these patients consist of individuals who have gone to African countries to work or individuals in their families. The remaining five (13.89\%) patients are citizens of the following countries; Tanzania (two), Democratic Republic of the Congo (one), Cameroon (one) and Chad (one), these people came to Turkey for work and holidays.

Examination of the distribution of malaria cases by months showed that the most cases occurred in June and August, in 
Table 1. The number of examined blood samples, the number of positive cases, the distribution of cases by gender, and the species of parasites according to years in Antalya between 2012 and 2017

\begin{tabular}{|c|c|c|c|c|c|c|c|c|}
\hline \multirow[t]{2}{*}{ Years } & \multirow{2}{*}{$\begin{array}{l}\text { The number of examined } \\
\text { blood samples }\end{array}$} & \multirow{2}{*}{$\begin{array}{l}\text { The number of } \\
\text { positive cases }\end{array}$} & \multicolumn{2}{|c|}{$\begin{array}{l}\text { The distrubution of } \\
\text { cases by gender }\end{array}$} & \multicolumn{4}{|c|}{ The species of parasites } \\
\hline & & & Male & Female & P. falciparum & P. vivax & P. ovale & P. malariae \\
\hline 2012 & 1269 & 9 & 7 & 2 & 6 & $3^{*}$ & 0 & 0 \\
\hline 2013 & 340 & 3 & 3 & 0 & 3 & 0 & 0 & 0 \\
\hline 2014 & 126 & 5 & 3 & 2 & 4 & 0 & 1 & 0 \\
\hline 2015 & 36 & 9 & 7 & 2 & 7 & 0 & 1 & 1 \\
\hline 2017 & 49 & 6 & 6 & 0 & 5 & 1 & 0 & 0 \\
\hline Total & 1905 & 36 & 30 & 6 & 29 & 4 & 2 & 1 \\
\hline
\end{tabular}

Table 2. Distribution of examined blood samples and positive cases by age groups and years in Antalya between 2012 and 2017

The number of examined blood samples and positive cases by years

\begin{tabular}{|c|c|c|c|c|c|c|c|}
\hline \multirow{2}{*}{\multicolumn{2}{|c|}{ 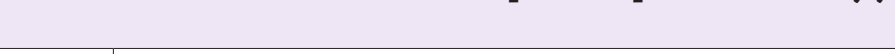 }} & \multirow{3}{*}{$\begin{array}{l}\mathbf{0 - 1} \\
0 \\
\end{array}$} & \multirow{3}{*}{$\begin{array}{l}\mathbf{1 - 4} \\
12\end{array}$} & \multirow{3}{*}{$\begin{array}{l}5-9 \\
22 \\
\end{array}$} & \multirow{3}{*}{$\begin{array}{l}\mathbf{1 0 - 1 4} \\
21\end{array}$} & \multirow{3}{*}{$\begin{array}{l}\mathbf{1 5 +} \\
1214\end{array}$} & \multirow{3}{*}{1269} \\
\hline & & & & & & & \\
\hline \multirow{2}{*}{2012} & The number of examined blood samples & & & & & & \\
\hline & The number of positive cases & 0 & 1 & 1 & 0 & 7 & 9 \\
\hline 2010 & The number of positive cases & 0 & 0 & 0 & 0 & 3 & 3 \\
\hline \multirow{2}{*}{2014} & The number of examined blood samples & 1 & 0 & 0 & 0 & 125 & 126 \\
\hline & The number of positive cases & 0 & 0 & 0 & 0 & 5 & 5 \\
\hline 2015 & The number of positive cases & 0 & 0 & 0 & 0 & 9 & 9 \\
\hline \multirow{2}{*}{2016} & The number of examined blood samples & 0 & 0 & 0 & 1 & 84 & 85 \\
\hline & The number of positive cases & 0 & 0 & 0 & 0 & 4 & 4 \\
\hline \multirow{2}{*}{2017} & The number of examined blood samples & 0 & 0 & 1 & 2 & 46 & 49 \\
\hline & The number of positive cases & 0 & 0 & 0 & 0 & 6 & 6 \\
\hline
\end{tabular}

Table 3. Distribution of the parasites responsible for malaria cases according to their sources and years in Antalya between 2012 and 2017

\begin{tabular}{|c|c|c|c|c|c|c|c|}
\hline \multirow{2}{*}{ Source of parasites } & \multicolumn{6}{|l|}{ Years } & \multirow{2}{*}{ Total } \\
\hline & 2012 & 2013 & 2014 & 2015 & 2016 & 2017 & \\
\hline Democratic Republic of the Congo & 2 & & & 1 & & & 3 \\
\hline Ghana & 4 & 2 & & & & & 6 \\
\hline Liberia & 1 & & & & & & 1 \\
\hline Gabon & & 1 & & & 1 & & 2 \\
\hline Mali & & & 1 & & & & 1 \\
\hline Tanzania & & & & 2 & 2 & & 4 \\
\hline Uganda & & & & 1 & & & 1 \\
\hline Cameroon & & & & 1 & & & 1 \\
\hline Niger & & & & 1 & & & 1 \\
\hline India & & & & & & 1 & 1 \\
\hline Chad & & & & & & 1 & 1 \\
\hline Total & 9 & 3 & 5 & 9 & 4 & 6 & 36 \\
\hline
\end{tabular}


which there were five cases each (13.89\%). The lowest number of cases occured in March, October and December in which there was one case each (2.78\%). However, malaria cases have been observed in all months during the six-year period. According to seasons, the most cases were found in summer (13 cases) followed by autumn and winter (eight cases for each one) and spring (seven cases) (Figure 1).

\section{DISCUSSION}

All of the detected malaria cases in Antalya province between 2012 and 2017 were from abroad which means that no indigenous malaria cases were observed in this period. The last indigenous case of malaria in Antalya province was reported in 2008 (1). All of the detected malaria cases have been imported cases since 2009. Similarly, indigenous cases of malaria were not reported in Turkey in 2010 and 2011. However, in 2012, the malaria epidemic occurred in Savur district of Mardin province, located in the Southeastern Anatolia Region of Turkey (15). According to WHO data, Turkey is currently among the countries that do not have indigenous malaria cases (9). It is thought that this positive development in terms of malaria result from depending on the progress in the health sector in Turkey the development of services for early diagnosis and treatment of the disease and effective vector control activity carried out by the Ministry of Health and municipalities (1,16). However, lack of an effective vaccine to protect people from malaria parasites, development of resistance in parasites against some drugs used in the treatment and development of resistance in mosquitoes to many insecticides used for vector control are serious risks for malaria control. Beside, increasing travel abroad for business, tourism and educational purposes due to the ease of transportation and large numbers of migrants arriving in our country due to the wars in our region are other important risk factors. In addition, there is a risk of malaria in our country which should not be ignored due to some factors such as many regions of Turkey have suitable ecological features for Anopheles mosquitoes and important effects of global warming and climate changes on vector and parasites (16-20).

In this study, $P$. falciparum was the causative agent of the vast majority of malaria cases (80.55\%). In accordance with our results, in the study performed in Elazığ province, the disease agent in 15 (88\%) of 17 malaria cases detected in the years 2011-

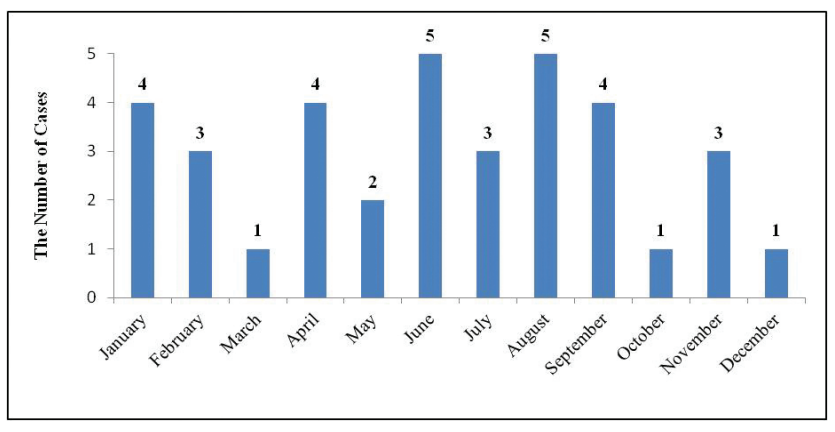

Figure 1. Distribution of malaria cases by months in Antalya between 2012 and 2017
2017 were P. falciparum, the other two (12\%) were P. vivax. All of these cases were imported and the majority of patients had a travel history to African countries (20). Similarly, in the studies carried out in recent years in Bursa, Hatay and Manisa provinces, it has been reported that $P$. falciparum was responsible for the vast majority of malaria cases and patients had a travel history especially to African countries $(19,21,22)$. In our study, it is thought that $P$. falciparum is high rate of causative agent among malaria cases due to the fact that all of the cases are from abroad and these patients had a travel history to African countries where the most common cases of malaria by $P$. falciparum are found in throughout the world or they came from these countries to Antalya. In the previous study in Antalya province, 66 malaria cases were detected between 2001 and 2011 and the species of parasite responsible for the disease in 57 (86\%) of these cases was $P$. vivax and in nine (14\%) was P. falciparum (1). Similarly, in previous studies in Adana, Mersin and Şanlıurfa provinces, $P$. vivax was responsible for the majority of malaria cases $(18,23,24)$. The findings of these studies are different from the findings obtained from our study. It was reported that most cases were seen in Southeastern Anatolia Region and Çukurova basin of Mediterranean Region in the years which found indigenous cases of malaria in Turkey (4). Plasmodium vivax was the parasite species responsible for the indigenous malaria cases in our country in this period, but imported malaria cases caused by $P$. falciparum have been frequently seen in recent years (2). In the light of this information, it is understandable to see difference between findings of our study and above studies. Because above studies were conducted in the period of the indigenous cases of malaria in Turkey. In addition, most of the detected cases in above studies were indigenous cases that caused by $P$. vivax.

Although malaria effects both males and females without considering gender differences, the majority of malaria patients (83.33\%) were males in our study. In the previous study conducted on the epidemiology of malaria in Antalya province between 2001 and 2011, a large majority (74\%) of the cases was males (1). In addition, the results of similar studies in Bursa (two studies), Çorum, Elazığ, Hatay, İstanbul, Kayseri, Kocaeli, Manisa and Mersin provinces were found to be consistent with the results of our study $(10,17,19-23,25-27)$. This situation can be attributed to the higher rate of males among Turkish citizens that have gone to countries where malaria is seen as endemic, especially from Antalya province for business, or among foreign nationals who come from these countries for business and tourism purposes.

When the malaria cases in our study were examined according to age groups, it was seen that $94.44 \%$ (34 cases) of the cases were in people 15 years old and over group. In the previous study conducted in Antalya province, 52 (78.8\%) of 66 malaria cases between 2001 and 2011 were reported to be in the 15 years old and over (1). Likewise, most of the malaria cases in the studies carried out in Adana, Bursa (two studies), Çorum, Hatay, Kayseri, Manisa, Mersin and Şanliurfa provinces were reported to be in the 15 years old and over group (10,17-19,21-24,26). This situation is thought to be because of the fact that individuals in the 15 
years old and over group travel more for business, education and tourism purposes, and they stay longer in outdoor areas compared to the other age groups during the active hours of mosquitoes.

There was a seasonal distribution of malaria cases in Turkey in the years of occurrence of indigenous malaria cases, depending on the climatical characteristics of our country. In these years, malaria cases were mostly seen in the period between April and November, when mosquitoes were active seasonally, especially in summer and autumn, while the least cases were seen in winter $(4,16)$. In addition, people spend more time in outdoor environments and travels also increase in these months $(1,23)$. In the previous study conducted in Antalya province, malaria cases were detected the highest in September (17 cases, 25.8\%) and the least in February (one case, 1.5\%) between 2001 and 2011. The seasonal distribution of cases was seen as follows, autumn (27 cases), summer (18 cases), spring (13 cases) and winter (eight cases), respectively (1). It was reported that the least cases were found in winter in the studies carried out in Adana (2002-2012), Mersin (2002-2011) and Şanliurfa (2001-2011) provinces where indigenous malaria cases were detected intensively $(18,23,24)$. Since the indigenous malaria cases have not been seen and all of cases have been imported from abroad, the seasonal distribution of malaria cases has been partially altered in Turkey in recent years. Currently, the seasonal distribution of malaria cases is thought to be dependent on international travel to countries where malaria is endemic. It is seen that the results of our study are compatible with this situation. For these reasons, it should be kept in mind malaria cases can be found throughout the year, and especially in winter months, patients who apply to health institutions with complaint of fever and with a travel history to countries where malaria is endemic should be evaluated in terms of malaria.

\section{CONCLUSION}

As a result of effective studies for control of malaria in Antalya and throughout Turkey, indigenous cases of malaria have not been observed in recent years. However, the climate, nature and human activities in Antalya provide a suitable environment for mosquitoes. In addition, intense population mobility due to factors such as tourism, education and migration increases the risk of malaria. For malaria control, studies on the early diagnosis and treatment of the disease and the integrated mosquito control programs should be uninterruptedly continued. Furthermore, people who will travel to the countries where the malaria is endemic should be informed about the disease and prevention methods and should be provided chemoprophylaxis for these people by Republic of Turkey Ministry of Health, Directorate General of Health for Border and Coastal Areas, Travel Health Centers.

\section{* Ethics}

Ethics Committee Approval: The ethics committee approval was not obtained due to the retrospective nature of the study.
Informed Consent: Retrospective study.

Peer-review: Internally peer-reviewed.

Financial Disclosure: The author declares that this study received no financial support.

Acknowledgements: The author thanks the staff of Antalya Provincial Directorate of Health, Infectious Diseases Unit and Kepez District Directorate of Health, Malaria Unit for their help in obtaining of the data used in the study.

\section{REFERENCES}

1. Ser Ö, Çetin H. Evaluation of malaria cases in Antalya between 2001 and 2011. Turkiye Parazitol Derg 2012;36:4-8.

2. World Health Organization. World malaria report 2011. Geneva: WHO Press; 2011.

3. Verra F, Angheben A, Martello E, Giorli G, Perandin F, Bisoffi Z. A systematic review of transfusion-transmitted malaria in non-endemic areas. Malar J 2018;17:36.

4. Akdur R. Sitma eğitim notları. Ankara: Cem Web Ofset Ltd Şti 1997.

5. Mejia GA, Alvarez CA, Pulido HH, Ramírez B, Cardozo C, Suárez Y, et al. Malaria in a liver transplant recipient: A case report. Transplant Proc 2006;38:3132-4.

6. Service M. Medical entomology for students. 5th ed. New York: Cambridge University Press; 2012.

7. Sinka ME, Bangs MJ, Manguin S, Rubio-Palis Y, Chareonviriyaphap $\mathrm{T}$, Coetzee M, et al. A global map of dominant malaria vectors. Parasit Vectors 2012;5:69.

8. Alten SB, Çağlar SS, Özer N. Malaria and its vectors in Turkey. European Mosq Bull 2000; 7: 27-33.

9. World Health Organization. World malaria report 2017. Geneva: WHO Press; 2017.

10. İnanç T, Kuk S, Yazar S. The epidemiology of malaria in Çorum between 2006 and 2011. Kafkas Univ Vet Fak Derg 2012;18:A97-A99.

11. Wongsrichanalai C, Barcus MJ, Muth S, Sutamihardja A, Wernsdorfer WH. A review of malaria diagnostic tools: microscopy and rapid diagnostic test (RDT). Am J Trop Med Hyg 2007;77:119-27.

12. Tangpukdee N, Duangdee C, Wilairatana P, Krudsood S. Malaria diagnosis: A brief review. Korean J Parasitol 2009;47:93-102.

13. World Health Organization. A global brief on vector-borne diseases. Geneva: WHO Press; 2014.

14. World Health Organization. World malaria report 2016. Geneva: WHO Press; 2016.

15. Eskiocak M, Karababa AO, Ceylan A, Saka G, Çiçek M. Mardin-Savur ilçesi sıtma salgınını inceleme ve değerlendirme raporu. 1. baskı. Ankara: Türk Tabipleri Birliği Yayınları 2012. ISBN 978-605-5867-67-6.

16. Özbilgin A, Topluoglu S, Es S, Islek E, Mollahaliloğlu S, Erkoc Y. Malaria in Turkey successful control and strategies for achieving elimination. Acta Trop 2011;120:15-23.

17. Uyar Y, İnanç T, Serkan S, Kuk S, Yazar S. The epidemiology of Malaria in Kayseri between 2001 and 2013. Turkiye Parazitol Derg 2015;39:86-9.

18. Yentür-Doni N, Yıldız-Zeyrek F, Seyrek A, Şimşek Z, Gürses G, Topluoğlu S. Evaluation of epidemiological data of malaria between 2001-2011 in Sanliurfa, Turkey. Mikrobiyol Bul 2016;50:307-14.

19. Çulha G, Yıldız-Zeyrek F, Önlen Y, Yentür-Doni N. Determination of imported malaria cases in Hatay by the use of molecular methods. Mikrobiyol Bul 2018;52:206-13. 
20. Sağmak-Tartar A, Akbulut A. Epidemiological, Clinical, and Laboratory Evaluation of Plasmodium falciparum Malaria Cases Followed in Firat University Hospital: A 6-Year Retrospective Analysis. Turkiye Parazitol Derg 2018;42:1-5.

21. Aksoy-Gökmen A, Pektaş B, Öncel K, Özdemir OA, Çavuş İ, Özbilgin A. The investigation of malaria cases in Manisa between 2008-2012. Turkiye Parazitol Derg 2014;38:151-4.

22. Alver O, Ener B. The Epidemiology of Malaria in Bursa between 2013 and 2014. Turk Hij Den Biyol Derg 2018;75: 37-42.

23. Aydin MF, Sahin A. Malaria epidemiology in Mersin province, Turkey from 2002 to 2011. Iranian J Parasitol 2013;8:296-301.
24. Kuşcu F, Öztürk DB, Gül S, Babayiğit ML. The epidemiology of malaria in Adana between 2002 and 2012. Turkiye Parazitol Derg 2014;38:147-50.

25. Arslan F, Mert A, Batirel A, Inan A, Balkan II, Nazlican O, et al. Imported Plasmodium falciparum malaria in Istanbul, Turkey: risk factors for severe course and mortality. Trop Doct 2013;43:129-33.

26. Alver O, Atıcı E, Göral G. The epidemiology of malaria in Bursa-2009-2012. Turkiye Parazitol Derg 2014;38:81-4

27. Sargın-Altunok E, Aynığlu A, Azak Karali E, Mutlu B, Willke A. Plasmodium falciparum malaria of foreign-origin in Kocaeli Province: Assessment of 16 cases. Klimik Dergisi 2016;29:86-89. 